\title{
Negative Consequences on the Growth, Morphometry, and Community Structure of the Kelp Macrocystis pyrifera (Phaeophyceae, Ochrophyta) by a Short Pollution Pulse of Heavy Metals and PAHs
}

\author{
Roddy Jara-Yáñez 1,2,3, Andrés Meynard 1,2,3,4, Gladys Acosta ${ }^{1}$, Nicolás Latorre-Padilla 1,2,3,4, \\ Carolina Oyarzo-Miranda 1,2,4 , Francisco Castañeda ${ }^{1,2}$, Florentina Piña 1,2,3,4 , Jorge Rivas 1,2,3,4, \\ Cristian Bulboa ${ }^{1,2, *}$ and Loretto Contreras-Porcia $1,2,3,4, * \mathbb{D}$
}

Citation: Jara-Yáñez, R.; Meynard, A.; Acosta, G.; Latorre-Padilla, N.; Oyarzo-Miranda, C.; Castañeda, F.; Piña, F.; Rivas, J.; Bulboa, C.; Contreras-Porcia, L. Negative Consequences on the Growth, Morphometry, and Community Structure of the Kelp Macrocystis pyrifera (Phaeophyceae, Ochrophyta) by a Short Pollution Pulse of Heavy Metals and PAHs. Toxics 2021, 9, 190. https://doi.org/10.3390/ toxics 9080190

\section{Received: 21 July 2021}

Accepted: 13 August 2021

Published: 18 August 2021

Publisher's Note: MDPI stays neutral with regard to jurisdictional claims in published maps and institutional affiliations.

Copyright: (c) 2021 by the authors. Licensee MDPI, Basel, Switzerland. This article is an open access article distributed under the terms and conditions of the Creative Commons Attribution (CC BY) license (https:// creativecommons.org/licenses/by/ $4.0 /)$.
1 Departamento de Ecología y Biodiversidad, Facultad de Ciencias de la Vida, Universidad Andres Bello, Santiago 8370251, Chile; roddy.jara@gmail.com (R.J.-Y.); meynardster@gmail.com (A.M.); gladyszoo@yahoo.es (G.A.); nlatorrepadilla@gmail.com (N.L.-P.); karo.oyarzo@gmail.com (C.O.-M.); fra.castaneda@gmail.com (F.C.); florentinapina1996@gmail.com (F.P.); jrivasperez@gmail.com (J.R.)

2 Centro de Investigación Marina de Quintay (CIMARQ), Facultad de Ciencias de la Vida, Universidad Andres Bello, Valparaiso, Quintay 2531015, Chile

3 Center of Applied Ecology and Sustainability (CAPES), Santiago 8331150, Chile

4 Instituto Milenio en Socio-Ecología Costera (SECOS), Santiago 8370251, Chile

* Correspondence: cbulboa@unab.cl (C.B.); lorettocontreras@unab.cl (L.C.-P.)

\begin{abstract}
The study of pollution effects in the marine environment has become important in recent decades, and the exposure to simultaneous pollutants has become especially relevant. Indeed, the study of key organisms, such as ecosystem engineers, can show a broader view of the effects of pollutants. In this context, we evaluate in situ the effects of a short (7-day) pollution pulse of combined solutions of heavy metals and polycyclic aromatic hydrocarbons (PAHs) ( $\mathrm{Cu}+\mathrm{PAHs}$, $\mathrm{Cd}+$ PAHs, $\mathrm{Cu}+\mathrm{Cd}$, and $\mathrm{Cu}+\mathrm{Cd}+\mathrm{PAHs}$ ) on the development and morphological features of Macrocystis pyrifera sporophytes over a period of 90 days. Additionally, we determined the effects on the community structure associated with this kelp. This study evidenced a smaller number of blades and a decreased size of blades and holdfasts, as well as the death of individuals exposed to a secondary mix of metals $(\mathrm{Cu}+\mathrm{Cd})$ and a tertiary mix of pollutants $(\mathrm{Cu}+\mathrm{Cd}+\mathrm{PAHs})$. Regarding the effects on the accompanying fauna, low richness and diversity were registered. M. pyrifera grazers, according to the mixture of pollutants, were either absent or diminished. These results show that the pulse of contamination in the early stages of $M$. pyrifera negatively affects its development and morphometry, as well as its role as an ecosystem engineer, due to a negative alteration in the species composition.
\end{abstract}

Keywords: community structure; ecosystem health; growth; heavy metals; Macrocystis pyrifera; marine contamination; morphometry; polycyclic aromatic hydrocarbons (PAHs)

\section{Introduction}

Coastal areas are particularly important, due to the high abundance and diversity of marine life. However, coastal zones all over the world have become extensively degraded by growing human occupation and an increase in toxic chemical discharges, which in turn negatively affects biodiversity and ecosystem services, among other effects [1]. Therefore, it is imperative to estimate the distribution patterns of pollutants in coastal regions and their potential impacts on marine ecosystems.

Throughout the Chilean coastline, high levels of heavy metals and polycyclic aromatic hydrocarbons (PAHs) have been found in seawater, sediments, and marine organisms [2-7]. Heavy metals are inorganic naturally occurring compounds in the marine environment, but 
their concentrations have increased significantly because of anthropogenic intervention $[1,8,9]$. Historically, heavy metals have been one of the most common pollutants in the Chilean shores, originating primarily from mining and industrial activities, as well as from other land-based discharges and atmospheric deposition. On the other hand, PAHs are persistent organic compounds found in coastal areas mainly because of human activities, such as land-based discharges, deposition, ship accidents, and, more frequently since the 1900s, the rise in oil spill events [6,10-13]. Given their mutagenic and carcinogenic properties, which cause significant risks to aquatic life [13], PAHs were included in the priority lists of pollutants of the European Union (EU) and the United States Environmental Protection Agency (EPA) and are currently on the hazardous substance lists provided by the Agency for Toxic Substances and Disease Registry (ATSDR).

Several authors have reported negative effects of heavy metals and PAHs at different biological levels in the marine environment, but these studies have mainly assessed the toxic effects of individual pollutants [14-17]. Nonetheless, the synergistic effects of heavy metals and PAHs have been recently documented [18-20], which is extremely worrying since both pollutants are frequently co-occurring in environmental matrices worldwide. The enrichment of coastal waters with chemical mixtures could increase, for example, the individual toxicity of heavy metals, and affect not only single species but also the diversity and structure of marine communities through cascading trophic consequences (bottom-up and top-down effects). However, it is known that the effects of pollutants are species- and even population-specific [16-20].

Foundation species are key taxa that increase food-web complexity and richness by creating habitats, influencing physical conditions, and influencing ecosystem processes [21-29]. Negative effects on foundation species (e.g., on their development, growth, and changes in physiological or morphological traits) impact multiple levels of biological organization, causing a reduction in biodiversity and disruptions in community structure and ecosystem services [7,30]. Macrocystis pyrifera (Linnaeus) C. Agardh has been described as a foundation species in subtidal coastal marine ecosystems worldwide [26,27]; it offers different habitats for various algae, invertebrate, and vertebrate species, and is an important food source for many grazers. Moreover, its biomass is directly related with species richness. Sporophytes of M. pyrifera, which correspond to the diploid macroscopic phase of the life cycle of this species, are highly tolerant to heavy metal exposure [30], and have been considered as biomonitors in field studies for heavy metal pollution due to their great capacity for bioaccumulation [31,32].

Despite the ecosystem importance of M. pyrifera and the negative effects caused by the exposure to high levels of heavy metals and PAHs in marine organisms, no studies have examined both the individual and combined effects of these toxics, nor their effects on its associated fauna/flora and community structure. In this context, the first objective of this study was to examine, in vitro and in field conditions, the direct effects of exposure to combined solutions of heavy metals and PAHs on the growth and morphology of juvenile sporophytes of M. pyrifera. The second objective was to study the growth of these juvenile individuals under field conditions and assess the indirect effects of toxics on its associated fauna/flora through community structure analyses.

\section{Materials and Methods}

\subsection{Exposure of M. pyrifera to Treatment}

A total of 250 juvenile sporophytes of $M$. pyrifera were used. These sporophytes were grown from spores under controlled conditions (as described by [33]) until blades were $5 \mathrm{~cm}$ in length. After this period, the sporophytes were randomly separated into 3 Erlenmeyer flasks of $2 \mathrm{~L}$ with 16 individuals per treatment and were subsequently exposed for 7 days to (i) $0.22 \mu \mathrm{m}$ filtered seawater (control condition), (ii) $\mathrm{Cu}+\mathrm{Cd}$, (iii) $\mathrm{Cu}+\mathrm{PAHs}$, (iv) $\mathrm{Cd}+\mathrm{PAHs}$, and (v) $\mathrm{Cu}+\mathrm{Cd}+$ PAHs. The specific concentration of each pollutant for the in vitro exposure treatments were according to the $\mathrm{EC}_{20}$ ( $20 \%$ effect concentration) values previously assessed for sporophyte development in our laboratory. In this previous study, independent $\mathrm{Cu}, \mathrm{Cd}$, and $\mathrm{PAH}$ (in vitro) treatments were carried out, where juvenile 
sporophytes were exposed during 7 days to the nominal concentrations of $\mathrm{Cu}, \mathrm{Cd}$ and PAHs in the ranges 5-200 $\mathrm{g} \mathrm{L} \mathrm{L}^{-1}, 5-200 \mu \mathrm{g} \mathrm{L}^{-1}$, and 0.05-100 $\mathrm{g} \mathrm{L}^{-1}$, respectively, determined on previous reports of $\mathrm{Cu}, \mathrm{Cd}$, and PAHs concentrations tested in seaweeds and other organisms from polluted environments [2,6,34]; then, $\mathrm{EC}_{20}$ values for $\mathrm{Cu}, \mathrm{Cd}$, and PAHs were determined using the ED function of the DRC package in the statistical environment $R$ (R Development Core Team 2020). Specifically, the nominal effective concentrations $E_{20}$ were $\mathrm{Cu}=190 \mu \mathrm{g} \mathrm{L}^{-1}, \mathrm{Cd}=155 \mu \mathrm{g} \mathrm{L}^{-1}$, and PAHs $=0.65 \mu \mathrm{g} \mathrm{L}^{-1}$. The stock solutions of each metal and the PAHs mixture were prepared from analytical reagent-grade copper chloride $\left(\mathrm{CuCl}_{2}\right.$, Titrisol ${ }^{\circledR}$, Merck, Darmstadt, Germany), cadmium chloride $\left(\mathrm{CdCl}_{2}\right.$ Titrisol ${ }^{\circledR}$, Merck, Darmstadt, Germany), and the reagent QTM PAH Mix (Supelco, Bellafonte, PA, USA). The PAH mixture used contained 16 compounds considered PAH-priority pollutants by the US EPA. All the glass and plastic materials used in the experiments were washed and rinsed according to [2] for metals, and US EPA Method 610 for PAHs. The culture conditions were as follows: $14{ }^{\circ} \mathrm{C}$, continued aeration provided by bubbling through air stones, a photoperiod of $12 \mathrm{~h}$ light and $12 \mathrm{~h}$ dark, and an irradiance of 30-40 $\mu \mathrm{mol}$ photons $\mathrm{m}^{-2} \mathrm{~s}^{-1}$.

\subsection{Growth and Morphometry}

After 7 days of exposure to experimental treatments, all M. pyrifera sporophytes were transferred to the sea (Quintay Bay, Valparaíso Region, Chile $\left(33^{\circ} 11^{\prime} 29^{\prime \prime}\right.$ S; $\left.71^{\circ} 42^{\prime} 16^{\prime \prime} \mathrm{W}\right)$ ) and cultured for 90 days during the spring and summer seasons (from September to December). Quintay is characterized by a sandy bottom and rocky boulders, with an average depth of $8 \mathrm{~m}$. Sporophytes from each treatment group were attached to a polypropylene rope $(5 \mathrm{~cm}$ long and $3 \mathrm{~mm} \varnothing)$ and then tied to a $7 \mathrm{~mm} \varnothing$ nylon rope in a long-line culture system.

To evaluate the effects of the treatments on the growth and morphometric characters, 5 sporophytes were sampled from each treatment at 30,60, and 90 days of culture. Specifically, for each treatment, the total wet weight was determined using a digital balance $( \pm 0.1 \mathrm{~g})$ (Kern, Balingen, Germany), the number of blades were counted, and the width and height of the holdfast and blade were measured.

\subsection{Community Structure}

To determine the community structure associated with $M$. pyrifera, 5 sporophytes were harvested for each treatment at 90 days of cultivation. Subsequently, the epibiontic organisms were manually collected and kept in plastic containers with 70\% ethanol-methanol 1:1 at $4{ }^{\circ} \mathrm{C}$ until identification using a stereomicroscope (Nikon SMZ1270, Tokyo, Japan). Additionally, the organisms were classified according to the thallus section where they were found, i.e., holdfast or blade. Finally, the organisms were identified at the lowest possible taxonomic level using specialized literature. The species richness, Shannon-Wiener diversity $\left(\mathrm{H}^{\prime}\right)$, and Simpson equitability $\left(\mathrm{D}^{\prime}\right)$ indices were calculated from the abundance data, obtaining proportional abundance within the samples. The Pielou index $\left(\mathrm{J}^{\prime}\right)$, which measures the proportion of the diversity observed in relation to the expected maximum, allowed us to observe the existence of dominant species in the samples. To obtain the similarity in species composition between the treatments, the Jaccard coefficient index (IJ) was calculated using species richness according to [7]. All community descriptors were calculated with the R software (R Development Core Team 2020), using the "BiodiversityR" and "vegan" packages, and the resulting values were classified as high, medium, or low according to the literature $[7,35,36]$.

\subsection{Statistical Analyses}

To evaluate the effects of the treatments and the time of culture on the morphological characteristics of kelps, a general linear model (GLM) analysis was employed, where morphology was considered a dependent variable, and treatments and time were considered independent variables. 
To evaluate the differences in the flora and fauna associated with $M$. pyrifera holdfasts and blades, Dunnett's analysis was carried out to assess significant differences in the community descriptors between treatments. For this, each community descriptor was used as the dependent variable, while the treatments were used as independent variables. Finally, for the Jaccard similarity coefficient, a dendrogram was generated using the "abe4" package from R software.

\section{Results}

\subsection{Growth and Morphometry of M. pyrifera}

A constant increase was registered in all morphological features in the control individuals, where the highest values recorded were principally on day 90 of culture (Figures 1 and 2 and Figure S1). On the other hand, the algae exposed to $\mathrm{Cu}+\mathrm{Cd}$ and $\mathrm{Cu}+\mathrm{Cd}+$ PAHs were not present in the culture line after 90 days of sea cultivation, strongly suggesting that the death of the individuals was due to the longer period of exposure to these toxicant mixtures. Additionally, these individuals presented the lowest values in all morphometric traits, especially those from the $\mathrm{Cu}+\mathrm{Cd}+$ PAHs treatment (Figures 1 and 2 and Figure S1). The results of the statistical analysis of the data are shown in Tables S1 and S2.

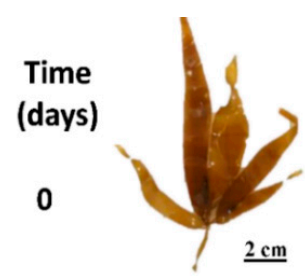

\section{Culture treatments}

Control $\mathrm{Cd}+\mathrm{PAHs} \quad \mathrm{Cu}+\mathrm{PAHs} \quad \mathrm{Cu}+\mathrm{Cd} \quad \mathrm{Cu}+\mathrm{Cd}+\mathrm{PAHs}$

30
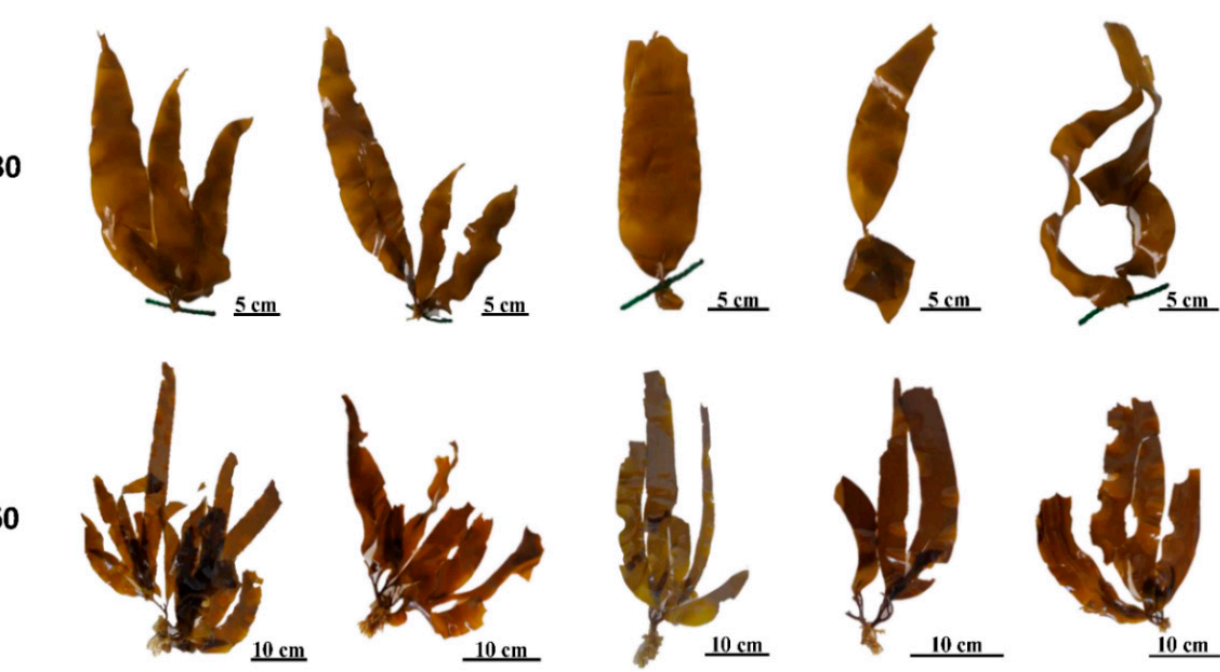

90
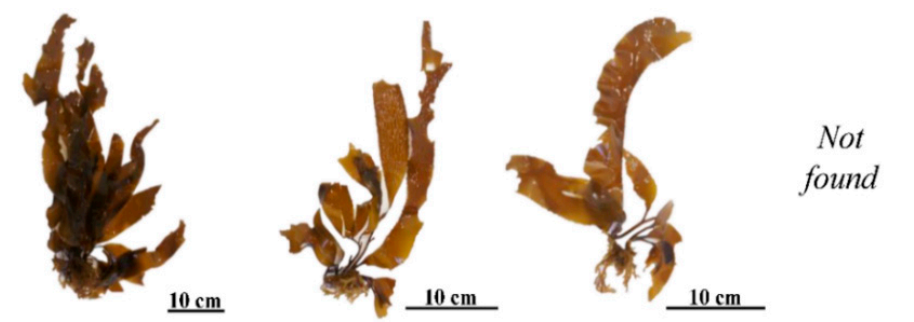

$$
\begin{gathered}
\text { Not } \\
\text { found }
\end{gathered}
$$

Figure 1. Representative images of Macrocystis pyrifera sporophyte from the control and from the heavy metal + PAHs treatments throughout the experimental period. Individuals from the treatments $\mathrm{Cu}+\mathrm{Cd}$ and $\mathrm{Cu}+\mathrm{Cd}+$ PAHs were not found at 90 days of culture. 
A

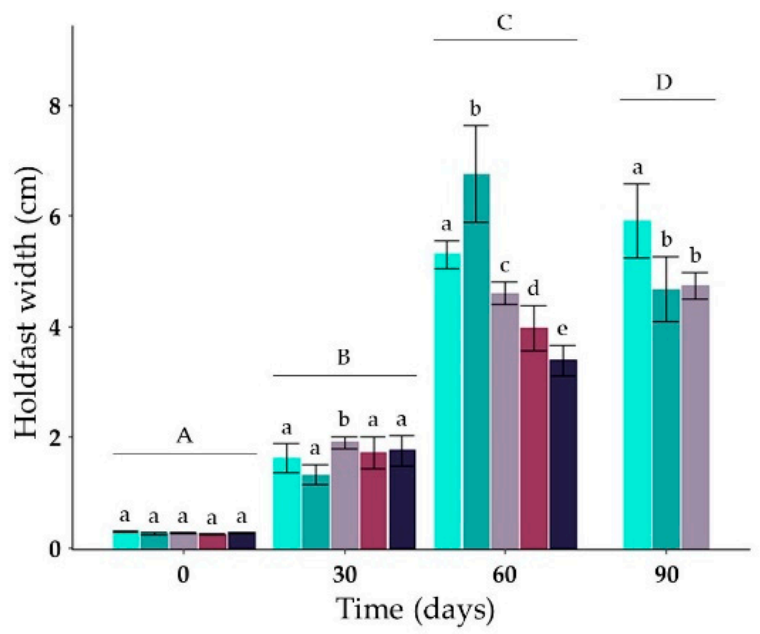

C

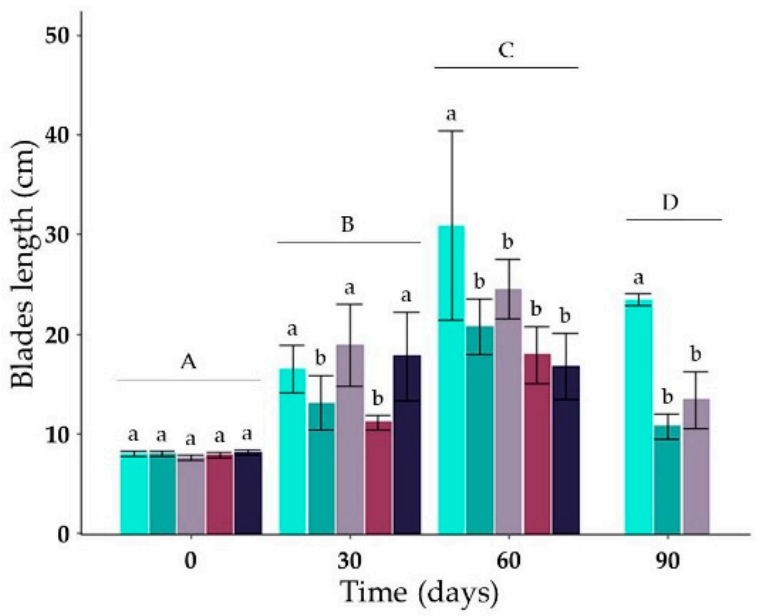

B

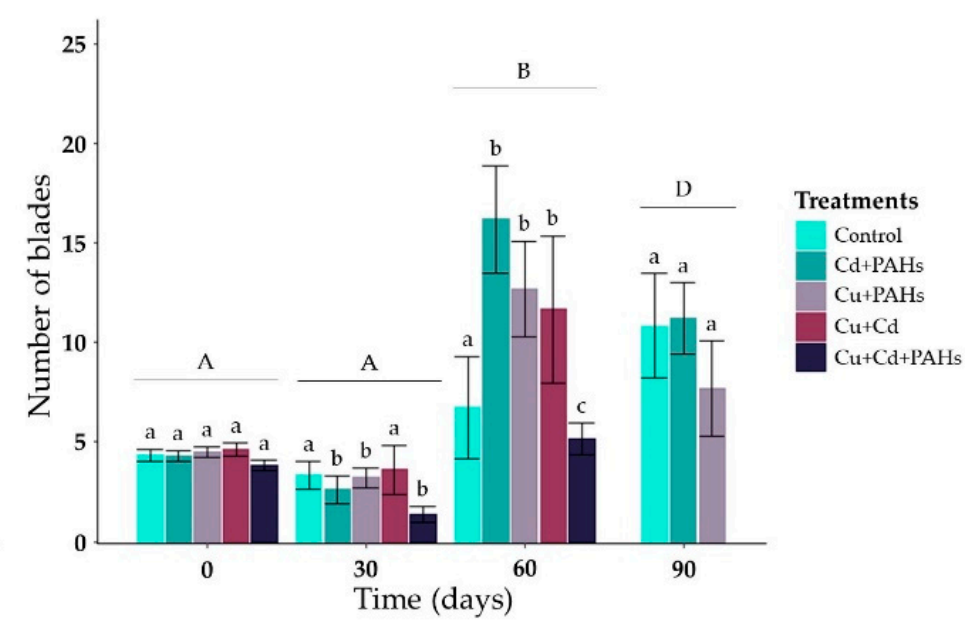

D

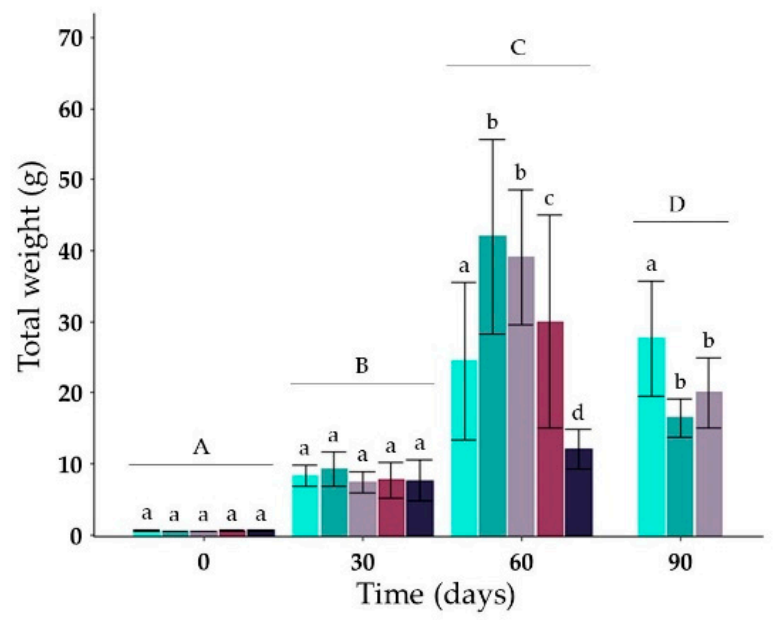

Figure 2. Morphometry of Macrocystis pyrifera: (A) holdfast width, (B) the number of blades, (C) blade length, and (D) total weight. $n=5 \pm$ standard error. The significant differences between the treatments are shown with small letters, with capital letters indicating the differences between the experimental times $(p<0.05)$.

The holdfast width of the control individuals increased 9.8 times after 60 days of culture, reaching $5.3 \pm 0.2 \mathrm{~cm}$ (Figure 2A). At this time, the thinnest holdfasts were recorded in the treatments $\mathrm{Cu}+\mathrm{Cd}$ and $\mathrm{Cu}+\mathrm{Cd}+\mathrm{PAHs}$, which had the lowest width of the period with $4.6 \pm 0.6 \mathrm{~cm}$ and $3.4 \pm 0.3 \mathrm{~cm}$, respectively. After 90 days, the holdfast width from the control individuals reached $6.7 \mathrm{~cm}$ on average, increasing 20 times in relation to the initial time (Figure 2A). The holdfast height (Figure S1A) of the control individuals $(5.3 \pm 0.5 \mathrm{~cm})$ increased 6.8 times after 60 days of culture. At this time, the individuals from the $\mathrm{Cu}+\mathrm{Cd}+\mathrm{PAHs}$ treatment presented the lowest average values $(4.1 \pm 0.5 \mathrm{~cm})$ (Figure S1A).

In relation to the number of blades, the individuals from the $\mathrm{Cd}+\mathrm{PAHs}$ treatment registered the largest values after 60 days of exposure compared to the initial cultivation time ( $4.3 \pm 0.3$ blades vs. $16.2 \pm 2.7$ blades) (Figure 2B). On the contrary, the lowest number of blades was registered in the individuals exposed to the treatments $\mathrm{Cu}+\mathrm{Cd}$ and $\mathrm{Cu}+\mathrm{Cd}+\mathrm{PAHs}$ (11.7 \pm 3.7 blades and $5.2 \pm 0.8$ blades, respectively) (Figure 2B). After 90 days, no statistical differences $(p>0.05)$ were registered between the individuals that 
survived from the three treatments. Specifically, at this time, the individuals presented an average of $10.8 \pm 2.6$ blades (control), $11.3 \pm 1.8$ blades ( $\mathrm{Cd}+\mathrm{PAHs})$, and $7.7 \pm 2.4$ blades $(\mathrm{Cu}+\mathrm{PAHs})$.

A constant increase in the length of the blades was observed over time, with the control group presenting the highest values (Figure 2C), which increased three times by day 60 of the culture in comparison with the initial time (Figure 2C). Additionally, the length of the blades in the control treatment was 1.4 and 1.2 times greater in relation to the $\mathrm{Cu}+\mathrm{Cd}+\mathrm{PAH}$ and $\mathrm{Cu}+\mathrm{Cd}$ treatments, respectively. On day 90, the control registered values were 1.6 and 2 times higher than the $\mathrm{Cd}+\mathrm{PAH}$ and $\mathrm{Cu}+\mathrm{PAH}$ treatments, respectively (Figure $2 \mathrm{C}$ ).

Regarding the total weight, significant differences were observed throughout the cultivation time. The lowest values were observed after 60 days in the individuals exposed to the $\mathrm{Cu}+\mathrm{Cd}+$ PAHs treatment $(12.0 \pm 2.8 \mathrm{~g})$, and these were $28 \%$ lower compared to the $\mathrm{Cd}+\mathrm{PAHs}(42.0 \pm 13.7 \mathrm{~g})$ and $48 \%$ lower compared to the control group $(24.5 \pm 11.1 \mathrm{~g})$ (Figure 2D). After 90 days, the highest weight values were recorded for the control group; these values were 50 times higher compared to the initial time $(27.7 \pm 8.1 \mathrm{~g})$ and 1.7 and 1.3 times higher than the $\mathrm{Cd}+$ PAHs $(16.5 \pm 2.7 \mathrm{~g})$ and $\mathrm{Cu}+$ PAHs $(20.0 \pm 4.9 \mathrm{~g})$, respectively (Figure 2D).

The holdfast weight showed a continuous increase during the experimental period, registering the first significant differences $(p<0.05)$ on day 60 of the culture, where the lowest values were recorded in the individuals exposed to the $\mathrm{Cu}+\mathrm{Cd}+\mathrm{PAHs}(2.4 \pm 0.4 \mathrm{~g})$ (Figure S1B). On day 90 of the culture, the highest holdfast weight values were recorded in the control group $(9.7 \pm 2.8 \mathrm{~g})$; they were 2.4 and 2.9 times higher than the $\mathrm{Cd}+\mathrm{PAHs}$ $(4.0 \pm 0.6 \mathrm{~g})$ and $\mathrm{Cu}+$ PAHs $(3.4 \pm 1.4 \mathrm{~g})$, respectively (Figure S1B). Finally, the weight of the blades presented the highest values on day 60 , and the low values were registered in individuals from the $\mathrm{Cu}+\mathrm{Cd}+$ PAHs treatment (10 $\pm 2.6 \mathrm{~g})$ (Figure S1C).

\subsection{Community Structure Associated with M. pyrifera}

A total of five phyla and 16 species were associated with $M$. pyrifera thalli; 12 species were found in the control, 10 in the $\mathrm{Cd}+$ PAHs treatment, and 8 in the $\mathrm{Cu}+$ PAHs treatment (Table 1 and Figure 3). The most representative species considering all parts of the kelp (blades plus holdfast) corresponded to Aora typica and Membranipora membranacea for all treatments, with $52 \%$ and $25.7 \%$ from control individuals, $19 \%$ and $28.6 \%$ from Cd + PAHs individuals, and $25.5 \%$ and $43.1 \%$ from $\mathrm{Cu}+$ PAHs individuals, respectively.

In the biodiversity analysis of $M$. pyrifera, it was found that, for all the organisms present in the holdfast, the most abundant corresponded to amphipods (72\%) and polychaetes $(18.3 \%$ ) considering all treatments (control $=83.7 \%$ and $8.7 \%, \mathrm{Cd}+\mathrm{PAHs}=35 \%$ and $45 \%$, and $\mathrm{Cu}+\mathrm{PAHs}=52.6 \%$ and $36.8 \%)$, the Gastropoda class $(0.8 \%)$ being less represented. The total organisms found in the blades reveal a greater abundance of those from the Bryozoa phylum, with M. membranacea $(61 \%)$ considering all treatments (control $=59.2 \%, \mathrm{Cd}+\mathrm{PAHs}=54.5 \%$, and $\mathrm{Cu}+\mathrm{PAHs}=69 \%$ ), while the less abundant organism corresponded to the Polychaeta class (6.4\%) in all treatments (control $=4.2 \%$, $\mathrm{Cd}+\mathrm{PAHs}=13.6 \%$, and $\mathrm{Cu}+$ PAHs $=6.3 \%$ ).

No significant differences were found in the Shannon-Wiener, Simpson, and Pielou indices between different parts of the kelp or between treatments $(p>0.05$ in all cases, according to Dunnett's test) (Figure 4). Nonetheless, the GLM analysis evidenced that these indices were mainly influenced by the localization of the organisms along the thallus (Figure 4 and Table S3). Particularly, the Shannon-Wiener index ranged between 0.42 and 1.16 (Figure 4A), indicating a low species diversity. The holdfast of M. pyrifera control presented the lowest species diversity $(0.57 \pm 0.08)$; on the contrary, a high diversity $(1.21 \pm 0.12)$ was observed when considering all thallus (blades plus holdfast) (Figure 4A). 
Table 1. Macroinvertebrates found in the holdfast and blades of Macrocystis pyrifera and their respective abundances, for algae exposed to a mixture of contaminants and the control group (without toxic exposure). ${ }^{*}$ Indicate species that feed on M. pyrifera.

\begin{tabular}{|c|c|c|c|c|c|c|c|}
\hline \multirow{3}{*}{ Phylum/Class } & \multirow{3}{*}{ Taxa } & \multicolumn{6}{|c|}{ Treatments } \\
\hline & & \multicolumn{2}{|c|}{ Control } & \multicolumn{2}{|c|}{ Cd + PAHs } & \multicolumn{2}{|c|}{$\mathrm{Cu}+$ PAHs } \\
\hline & & Holdfast & Blades & Holdfast & Blades & Holdfast & Blades \\
\hline \multicolumn{8}{|l|}{ Arthropoda } \\
\hline \multirow{8}{*}{ Malacostraca } & Aora typical * & 77 & 9 & 7 & 1 & 10 & 3 \\
\hline & Sunamphitoe femorata * & - & 4 & - & 1 & - & 1 \\
\hline & Pilumnoides perlatus & - & 1 & - & 1 & - & - \\
\hline & Taliepus dentatus * & 4 & 7 & 3 & 2 & 2 & 1 \\
\hline & Erichthonius sp. & 2 & - & 1 & - & - & - \\
\hline & Amphipoda sp.1 & - & - & - & 2 & - & 2 \\
\hline & Amphipoda sp.2 & - & 3 & - & - & - & - \\
\hline & Amphipoda sp.3 & - & 2 & - & - & - & - \\
\hline \multicolumn{8}{|l|}{ Annelida } \\
\hline \multirow[t]{4}{*}{ Polychaeta } & Platynereis australis & 6 & 3 & 6 & 1 & 5 & 2 \\
\hline & Pseudonereis sp. & 1 & - & - & - & - & - \\
\hline & Phyllodocidae & - & - & - & 2 & - & - \\
\hline & Terebellidae & 1 & - & 3 & - & 2 & - \\
\hline Mollusca & & & & & & & \\
\hline $\begin{array}{c}\text { Gastropoda } \\
\text { Bryozoa }\end{array}$ & Eatoniella sp.* & 1 & - & - & - & - & - \\
\hline Gymnolaemata & $\begin{array}{c}\text { Membranipora } \\
\text { membranacea }\end{array}$ & - & 42 & - & 12 & - & 22 \\
\hline Foraminifera & Foraminifera & - & - & - & - & - & 1 \\
\hline Tota & individuals & 92 & 71 & 20 & 22 & 19 & 32 \\
\hline Tot & l identities & 7 & 8 & 5 & 8 & 4 & 7 \\
\hline
\end{tabular}

Despite non-statistically significant results, the Simpson (Figure 4B) and Pielou indices (Figure 4C) revealed clear differences between the treatments. In terms of the holdfast, a low species dominance was observed for all treatments (control $=0.38 \pm 0.15$; $\mathrm{Cd}+$ PAHs $=0.23 \pm 0.15 ; \mathrm{Cu}+$ PAHs $=0.36 \pm 0.14)($ Figure $4 \mathrm{~B})$. The holdfasts from the $\mathrm{Cd}+$ PAHs treatment presented low species evenness $(0.34 \pm 0.22)$ (Figure $4 \mathrm{C})$, contrary to the control and the $\mathrm{Cu}+$ PAHs treatment, which showed an intermediate evenness $(0.5 \pm 0.19$ and $0.61 \pm 0.21$, respectively). On the other hand, the control and Cd PAHs treatments displayed a low species dominance $(0.46 \pm 0.08$ and $0.51 \pm 0.1$, respectively) on the blades, in contrast to the $\mathrm{Cu}+$ PAHs, which had an intermediate dominance $(0.58 \pm 0.04)$ (Figure $4 \mathrm{~B})$. Considering all parts of the kelp, an intermediate species dominance was found in the control $(0.6 \pm 0.06)$ and $\mathrm{Cu}+$ PAHs treatments $(0.56 \pm 0.1)$, whereas a high dominance was found in the $\mathrm{Cd}+$ PAHs treatment $(0.62 \pm 0.05)$ (Figure 4B). All treatments exhibited high species evenness, taking into consideration all parts of the kelp (control $=0.79 \pm 0.04 ; \mathrm{Cd}+\mathrm{PAHs}=0.72 \pm 0.2 ; \mathrm{Cu}+\mathrm{PAHs}=0.8 \pm 0.1$ ), revealed by the Pielou index (Figure 4C).

The dendrogram based on the Jaccard index showed a clear separation between the control and the groups exposed to binary mixtures of toxics (Figure 5A). A similar pattern was observed for the holdfast (Figure 5B). Nonetheless, on the blades, the first group was composed of individuals exposed to the $\mathrm{Cd}+\mathrm{PAH}$ binary mixture and the control, and the second group included algae from the $\mathrm{Cu}+$ PAHs treatment (Figure 5C). 


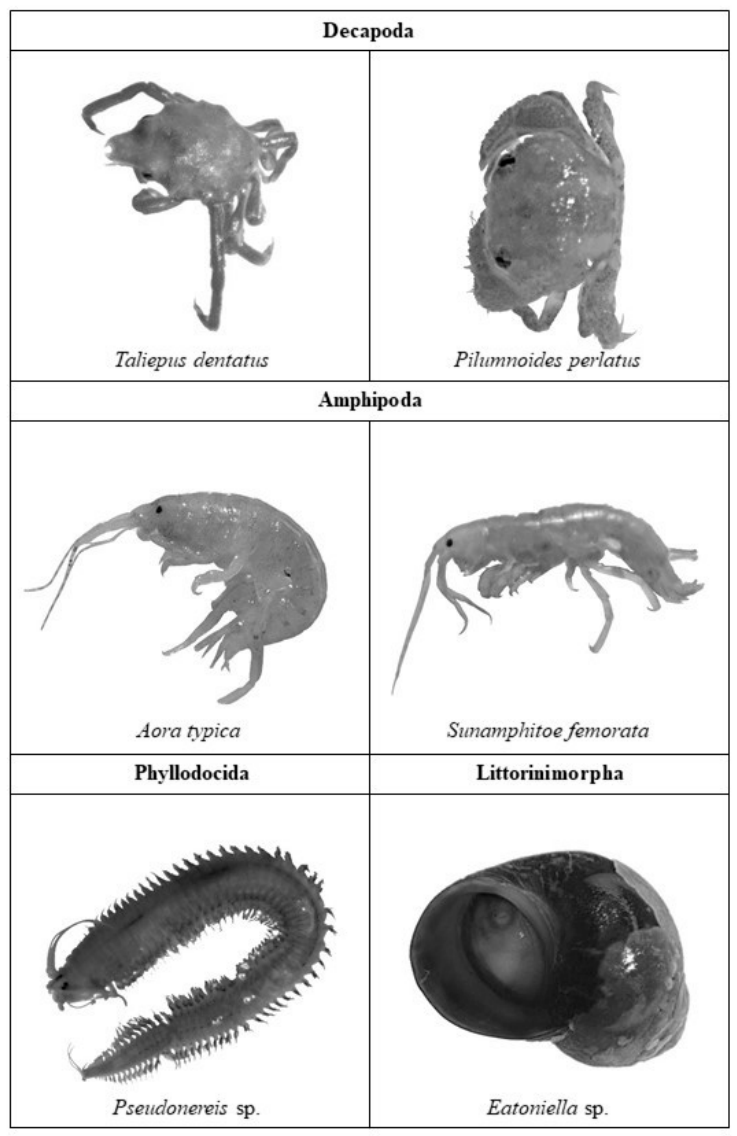

Figure 3. Representative images of the identified species associated with Macrocystis pyrifera thallus.

A

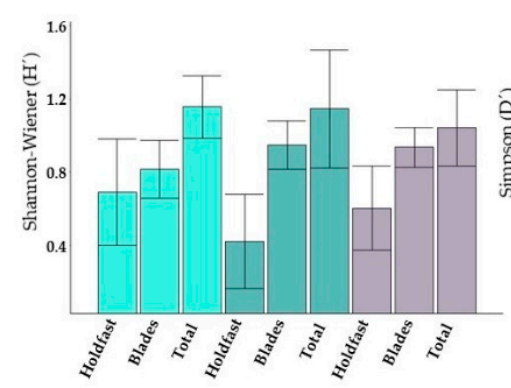

C

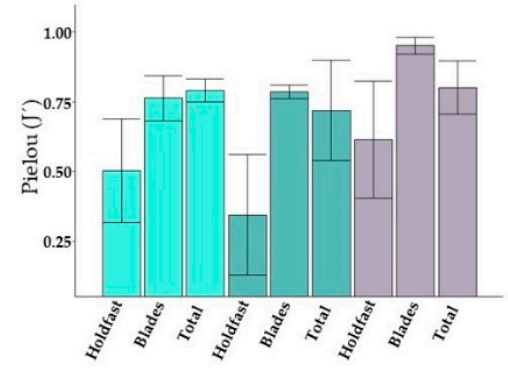

B

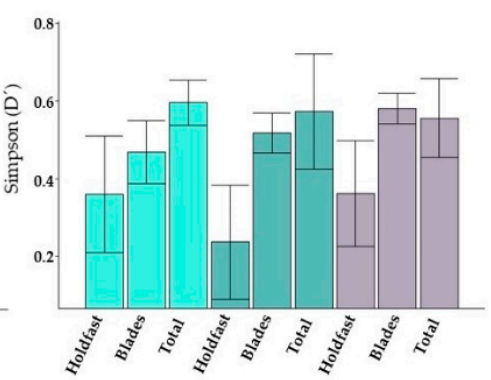

Figure 4. Community index determined in the holdfast, the blades, and the total (complete) thallus of Macrocystis pyrifera subject to different treatments (control, $\mathrm{Cd}+\mathrm{PAHs}$, and $\mathrm{Cu}+\mathrm{PAHs}$ ). ShannonWiener (A), Simpson (B), and Pielou (C) indexes. $n=5 \pm$ standard error. 
A

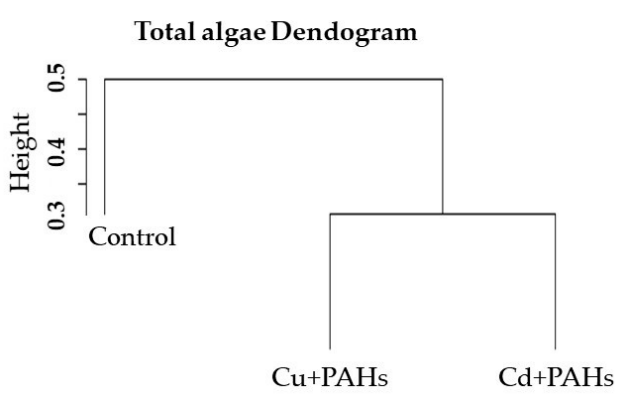

C

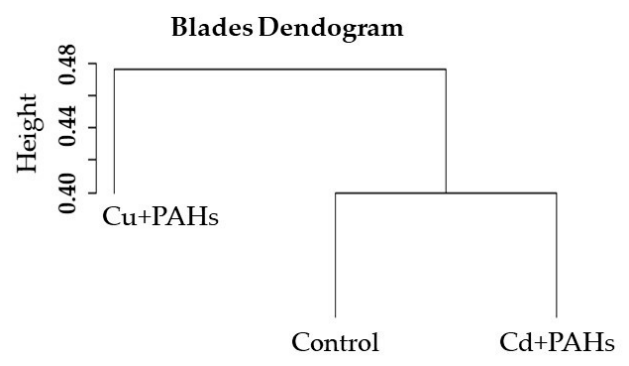

B

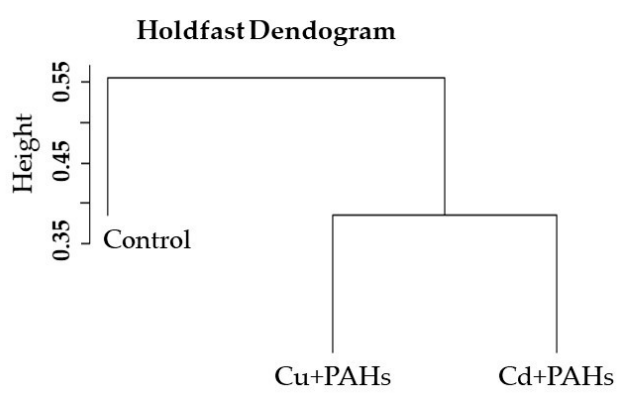

Figure 5. Dendrogram of the Jaccard similarity coefficient for the fauna associated with Macrocystis pyrifera. (A) Total algae, (B) holdfasts, and (C) blades. The values are in a range from 0 to 1 .

\section{Discussion}

The development of $M$. pyrifera sporophytes were negatively affected by a short pulse of exposure to mixtures of contaminants (heavy metals and PAHs), with visible morphological and development differences. The greatest negative effects were observed in the individuals exposed to $\mathrm{Cu}+\mathrm{Cd}$ and $\mathrm{Cu}+\mathrm{Cd}+$ PAHs regarding the weight, height, and width of the holdfast, the number of blades, and the length and weight of the blades. On the other hand, the role of $M$. pyrifera as an ecosystem engineer was also affected by pollutants, which modified the structure of the associated fauna and reduced the abundance of grazers. Concerning the community descriptors, although there were clear differences in some indices, no statistically significant differences were registered between the treatments. However, the Jaccard index showed groupings that suggest disparity and distinctive effects of the toxic mixtures on the community structure. In this way, this work evidenced the negative effects caused by the combination of heavy metals and PAHs on the development of M. pyrifera and its ecological role in the subtidal ecosystem.

The field experiments showed that, on day 90 of the culture post-exposure, the $\mathrm{Cu}+\mathrm{Cd}$ and $\mathrm{Cu}+\mathrm{Cd}+$ PAHs treatments exerted a negative effect on $M$. pyrifera. It has been widely shown that $\mathrm{Cu}$ generates reactive oxygen species (ROS) that damage the cellular components of seaweeds capable of inhibiting photosynthesis, reducing both their pigments and growth [37]. On the other hand, similar effects have been described in seaweeds exposed to $\mathrm{Cd}$, the most widely described being the inhibition of photosynthesis, the degradation of pigments, and the denaturation of fatty acids by ROS [38-40]. The equitoxic mixture of $\mathrm{Cu}+\mathrm{Cd}$ has been described as showing an antagonistic interaction effect, since these metals compete for active sites in the cell, but also as showing additive or synergistic effects, depending on the life cycle stage or the species being evaluated, and depending on the specific metabolic regulation of different metals at the cellular level. In the case of M. pyrifera, it has been observed that, in early stages of development, the binary mixture of these heavy metals generates antagonistic effects [19]. In addition, in the microalga Chlorella sp. at the cellular level, $\mathrm{Cd}$ and $\mathrm{Cu}$ co-exposure increases $\mathrm{Cu}$ (extracellularly and intracellularly) but inhibits $\mathrm{Cd}$ uptake, compared to each metal present by itself [40]. The same trend has been verified in a previous study in the kelp Lessonia berteroana, where, 
in Cu-polluted coastal areas, compared to reference sites without co-exposure with $\mathrm{Cd}$, the $\mathrm{Cd}$ concentrations in algal tissues were much lower, and $\mathrm{Cu}$ levels, on the contrary, were much higher [41]. However, the results obtained in this work do not agree with those findings, since the $\mathrm{Cu}+\mathrm{Cd}$ mixture was one of the mixtures that generated the greatest negative effects on the development of $M$. pyrifera; we therefore suggest a significant incorporation/effects of both heavy metals with the kelp tissue.

It has been previously described that PAHs exposure generates ROS and decreases the fluidity and conductivity of the membranes [42,43]. In addition, synergistic effects have been determined for exposure to heavy metals and PAH mixtures, because both affect the fluidity of the membrane and its ionic balance, which positively influence the entry of heavy metals into the cell [44]. This agrees with the results obtained in this work, where the $\mathrm{Cu}+\mathrm{Cd}+$ PAHs mixture generated the greatest effects on the development of $M$. pyrifera. In fact, the individuals of $M$. pyrifera exposed to this mixture of pollutants showed the greatest negative effects on their development $(\mathrm{Cd}+\mathrm{Cu}$ and $\mathrm{Cd}+\mathrm{Cu}+\mathrm{PAHs})$ and did not survive after day 60 , with no thalli of this treatment found on day 90 of the culture. One possible explanation for this is that exposure to the $\mathrm{Cu}+\mathrm{Cd}+$ PAHs caused the death of the M. pyrifera individuals due its high toxicity and synergistic interaction. Similar results were determined in the Lessonia spicata kelp using seawater (as a culture medium) from sites highly impacted by heavy metal and PAHs pollution [2]. Particularly, in vitro experiments with field-collected seawater showed that sites with high anthropogenic contamination induce sublethal effects on early developmental stages and, consequently, on seaweed populations, which in turn can also have long-term negative impacts on the community structure.

Regarding the fauna associated with M. pyrifera, 16 species were found (Table 1), which is considered low compared to what has been reported in natural beds [45,46]. Among the species found, the most abundant corresponded to the amphipod A. typica, followed by the bryozoan M. membranacea. The greatest abundance of $A$. typica is found in the holdfast together with P. australis, while M. membranacea is found exclusively in the blades. This agrees with what was previously described by [47,48], which indicates that the life cycle of these organisms develops mainly on the fronds of their algae host, reaching its highest abundance in the spring and summer periods. On the other hand, in the holdfast, the presence of sedentary tubicolous (Terebellidae) and mobile polychaetes was mainly recorded, which are mainly detritivores (Phyllodocidae, Pseudonereis, and P. australis) [49], as well as a species of crab of the genus Taliepus (T. dentatus), which have been described as common inhabitants of the kelp forest [50] and as important predators of M. pyrifera [51].

The absence of endophytic and epiphytic algae could be explained by certain traits of brown algae, such as M. pyrifera, which are able to chelate and exude metals through the generation of mucilage under contamination exposure. This allows them to generate high contaminant concentrations on their surface, inhibiting the settlement of other algal species [52]. Indeed, recent studies have proven the negative effects on the settlement and germination of algae exposed to seawater from zones polluted with these toxics [2].

The community indices showed low diversity and abundance values, in comparison to other reports. These differences could be explained mostly by the size of the algae, since Miller et al. [29] showed that there is a direct relationship between size of the algae and the number of associated species. Although there were no significant statistical differences in the community indices of the control algae compared with those exposed to the binary mixtures of pollutants $(\mathrm{Cd}+\mathrm{PAHs}$ and $\mathrm{Cu}+\mathrm{PAHs})$, the dendrogram for the holdfast community based on the Jaccard index generated two groups, separating the algae of the control from that of these two mixtures-treatments that survived until day 90 of exposure. This disparity can be explained by the species present. In the case of the total algae of the control treatment, a greater abundance of organisms such as the amphipod $A$. typica and the bryozoan $M$. membranacea were registered, as were some exclusive species (Amphipoda sp. 2 and 3, Pseudonereis sp., and Eatoniella sp.) (Table 1). Likewise, in the case of the holdfast, a greater abundance of total organisms and a high abundance of A. typica 
were found in the control treatment, in addition to the presence of two exclusive species (Pseudonereis sp. and Eatoniella sp.) (Table 1). These differences could be the main reason that the Jaccard index separates the control treatment from algae exposed to contaminants. On the other hand, in the case of the organisms found in the blades, the dendrogram grouped the control algae with those exposed to $\mathrm{Cd}+\mathrm{PAHs}$. This can be explained because the $\mathrm{Cu}+\mathrm{PAHs}$ treatment presents a lower richness and abundance, along with an accidental species (Foraminifera) (Table 1). Another difference is the number of organisms that feed on M. pyrifera, which present a higher abundance in the control group compared to other treatments. This is mainly due to the state of the algae, since it has been shown that pollutants change the palatability of algae, reducing their consumption by predators [53], preferring algae that have not been exposed to a secondary mixture of pollutants.

\section{Conclusions}

This work evidenced the damage produced by a short pollution pulse in early M. pyrifera sporophytes, affecting its development and consequently its role as an ecosystem engineer. More specifically, this work revealed a decrease in the size and number of blades, a smaller holdfast, and even the death of $M$. pyrifera sporophytes exposed to a binary mixture of heavy metals and a tertiary mixture of pollutants, especially those exposed for a longer period of time. In addition, a low richness, diversity, and evenness was revealed in the sporophytes treated with toxic mixtures, compared to those of the control, likely due to a lower number of species associated with $M$. pyrifera holdfasts with smaller sizes and fewer blades. These alterations of $M$. pyrifera are likely to have important impacts on the community structure, which could also affect superior organisms in the trophic web such as mobile predators.

Supplementary Materials: The following are available online at https://www.mdpi.com/article/ 10.3390/toxics9080190/s1, Figure S1: Morphometry of M. pyrifera: holdfast height (A), holdfast weight (B), and blade weight (C), Table S1: Analysis of variance (ANOVA) of a generalized linear model (GLM) of morphometric measurements (blade length, the number of blades, and blade weight) at 90 days of cultivation in response to combined contaminants $(\mathrm{Cu}+\mathrm{Cd}, \mathrm{Cu}+\mathrm{PAHs}$, $\mathrm{Cd}+\mathrm{PAHs}$, and $\mathrm{Cu}+\mathrm{Cd}+\mathrm{PAHs}$ ). Table S2: Analysis of variance (ANOVA) of a generalized linear model (GLM) on morphometric measurements (holdfast width, height, weight, and total weight) at 90 days of cultivation in response to combined contaminants $(\mathrm{Cu}+\mathrm{Cd}, \mathrm{Cu}+\mathrm{PAHs}, \mathrm{Cd}+\mathrm{PAHs}$, and $\mathrm{Cu}+\mathrm{Cd}+\mathrm{PAHs}$ ). Table S3: Analysis of variance (ANOVA) of a generalized linear model (GLM) of the community descriptors (Shannon-Wiener, Simpson, and Pielou) at 90 days of cultivation in response to combined contaminants $(\mathrm{Cu}+\mathrm{Cd}, \mathrm{Cu}+\mathrm{PAHs}, \mathrm{Cd}+\mathrm{PAHs}$, and $\mathrm{Cu}+\mathrm{Cd}+\mathrm{PAHs})$.

Author Contributions: L.C.-P., C.B. and R.J.-Y. conceived the project and designed the experiments. R.J.-Y., N.L.-P. and F.C. carried out the experiments. Material preparation and data collection and analysis were performed by R.J.-Y., F.P., N.L.-P., J.R., C.O.-M., G.A., A.M., C.B. and L.C.-P. The first draft of the manuscript was written by R.J.-Y., C.O.-M., G.A., F.P., C.B., L.C.-P. and A.M. and all authors commented on previous versions of the manuscript. Review and editing were performed by R.J.-Y. and L.C.-P. All authors have read and agreed to the published version of the manuscript.

Funding: This work was funded by ANID/ FONDECYT N ${ }^{\circ} 1170881$, ANID PIA/BASAL FB0002, and the ANID Millennium Science Initiative Program ICN 2019_015.

Institutional Review Board Statement: Not applicable.

Informed Consent Statement: Not applicable.

Data Availability Statement: Derived data supporting the findings of this study are available from the corresponding authors (L. Contreras-Porcia and C. Bulboa) on request.

Acknowledgments: We thank LEBMA (www.lebma.cl, accessed on 17 August 2021) for technical support and the "Pescadores Artesanales, Buzos, Mariscadores y Ramos Similares de Caleta Horcón" and "Sindicato de Pescadores Artesanales de Caleta Quintay" union for providing access to their protected area. We also thank Fernanda Oyarzun and Dario Navarrete, who developed the graphical abstract in the context of a project investigating visualizations in science. 
Conflicts of Interest: All authors certify that they have no affiliations with or involvement in any organization or entity with any financial interest. The authors declare that there is no conflict of interest.

\section{References}

1. Johnston, E.L.; Mayer-Pinto, M.; Crowe, T.P. Chemical contaminant effects on marine ecosystem functioning. J. Appl. Ecol. 2015, 52, 140-149. [CrossRef]

2. Oyarzo-Miranda, C.; Latorre, N.; Meynard, A.; Rivas, J.; Bulboa, C.; Contreras-Porcia, L. Coastal pollution from the industrial park Quintero Bay of central Chile: Effects on abundance, morphology, and development of the kelp Lessonia spicata (Phaeophyceae). PLoS ONE 2020, 15, e0240581. [CrossRef]

3. Zapata, M.; Lang, M.; Riso, R.; Moraga, D.; Riquelme, C. Trace metal and biomarker levels in tissues of Argopecten purpuratus in the north of Chile, and the potential use of this species as a bioindicator of metallic stress. Aquat. Living Resour. 2012, 25, 259-267. [CrossRef]

4. Valdés, J.; Guiñez, M.; Castillo, A.; Vega, S.E. Cu, Pb, and Zn content in sediments and benthic organisms from San Jorge Bay (northern Chile): Accumulation and biotransference in subtidal coastal systems. Cienc. Mar. 2014, 40, 45-58. [CrossRef]

5. Parra, S.; Bravo, M.A.; Quiroz, W.; Querol, X.; Paipa, C. Distribution and pollution assessment of trace elements in marine sediments in the Quintero Bay (Chile). Mar. Pollut. Bull. 2015, 99, 256-263. [CrossRef] [PubMed]

6. Latorre-Padilla, N.; Meynard, A.; Oyarzun, F.X.; Contreras-Porcia, L. Ingestion of contaminated kelps by the herbivore Tetrapygus niger: Negative effects on food intake, growth, fertility, and early development. Mar. Pollut. Bull. 2021, 167, 112365. [CrossRef]

7. Medina, M.; Andrade, S.; Faugeron, S.; Lagos, N.; Mella, D.; Correa, J.A. Biodiversity of rocky intertidal benthic communities associated with copper mine tailing discharges in northern Chile. Mar. Pollut. Bull. 2005, 50, 396-409. [CrossRef]

8. Ansari, T.M.; Marr, I.L.; Tariq, N. Heavy metals in marine pollution perspective-a mini review. J. Appl. Sci. 2004, 4, 1-20. [CrossRef]

9. Li, Z.; Ma, Z.; Van der Kuijp, T.J.; Yuan, Z.; Huang, L. A review of soil heavy metal pollution from mines in China: Pollution and health risk assessment. Sci. Total Environ. 2014, 468-469, 843-853. [CrossRef]

10. Recabarren-Villalón, T.; Orazi, M.M.; Ronda, A.C.; Marcovecchio, J.E.; Arias, A.H. Hidrocarburos Aromáticos Policíclicos (HAPs) en ambientes marinos: Una revisión de América. JAINA Cost. Mar. Cam. Clim. 2019, 1, 19-40.

11. Meador, J.P.; Casillas, E.; Sloan, C.A.; Varanasi, U. Comparative bioaccumulation of polycyclic aromatic hydrocarbons from sediment by two infaunal invertebrates. Mar. Ecol. Prog. Ser. 1955, 123, 107-124. [CrossRef]

12. Sinaei, M.; Mashinchian, A. Polycyclic aromatic hydrocarbons in the coastal sea water, the surface sediment and Mudskipper Boleophthalmus dussumieri from coastal areas of the Persian Gulf: Source investigation, composition pattern and spatial distribution. J. Environ. Health Sci. Eng. 2014, 12, 59. [CrossRef] [PubMed]

13. Abdel-Shafy, H.I.; Mansour, M.S. A review on polycyclic aromatic hydrocarbons: Source, environmental impact, effect on human health and remediation. Egypt. J. Pet. 2016, 25, 107-123. [CrossRef]

14. Golovanova, I.L. Effects of heavy metals on the physiological and biochemical status of fishes and aquatic invertebrates. Inland Water Biol. 2008, 1, 93-101. [CrossRef]

15. Contreras, L.; Mella, D.; Moenne, A.; Correa, J.A. Differential responses to copper-induced oxidative stress in the marine macroalgae Lessonia nigrescens and Scytosiphon lomentaria (Phaeophyceae). Aquat. Toxicol. 2009, 94, 94-102. [CrossRef]

16. Wang, L.; Zheng, B. Toxic effects of fluoranthene and copper on marine diatom Phaeodactylum tricornutum. J. Environ. Sci. 2008, 20, 1363-1372. [CrossRef]

17. Wang, X.; Zhu, X.; Chen, X.; Lv, B.; Wang, X.; Wang, D. Phenanthrene and pyrene disturbed the growth of Microcystis aeruginosa as co-cultured with Chlorella pyrenoidosa. Environ. Sci. Pollut. Res. Int. 2020, 27, 45957-45964. [CrossRef]

18. Espinoza-González, C.; Meynard, A.; Núñez, A.; Castañeda, F.; Oyarzo-Miranda, O.; Rivas, J.; Contreras-Porcia, L. Assessment of the independent and combined effects of Copper and Polycyclic Aromatic Hydrocarbons on gametophytes and sporophytes development of the kelp Lessonia spicata (Phaeophyceae, Ochrophyta). J. Appl. Phycol. 2021, in press. [CrossRef]

19. Meynard, A.; Espinoza-González, C.; Núñez, A.; Castañeda, F.; Contreras-Porcia, L. Synergistic, antagonistic, and additive effects of heavy metals (copper and cadmium) and polycyclic aromatic hydrocarbons (PAHs) under binary and tertiary combinations in key habitat-forming kelp species of Chile. Environ. Sci. Pollut. Res. 2021, 28, 18300-18307. [CrossRef] [PubMed]

20. Chen, S.; Qu, M.; Ding, J.; Zhang, Y.; Wang, Y.; Di, Y. BaP-metals co-exposure induced tissue-specific antioxidant defense in marine mussels Mytilus coruscus. Chemosphere 2018, 205, 286-296. [CrossRef] [PubMed]

21. Angelini, C.; Altieri, A.H.; Silliman, B.R.; Bertness, M.D. Interactions among foundation species and their consequences for community organization, biodiversity, and conservation. BioScience 2011, 61, 782-789. [CrossRef]

22. Borst, A.C.; Verberk, W.C.; Angelini, C.; Schotanus, J.; Wolters, J.W.; Christianen, M.J.; van der Zee, E.M.; van der Heide, T. Foundation species enhance food web complexity through non-trophic facilitation. PLoS ONE 2018, 13, e0199152. [CrossRef] [PubMed]

23. Thomson, J.A.; Burkholder, D.A.; Heithaus, M.R.; Fourqurean, J.W.; Fraser, M.W.; Statton, J.; Kendrick, G.A. Extreme temperatures, foundation species, and abrupt ecosystem change: An example from an iconic seagrass ecosystem. Glob. Chang. Biol. 2015, 21, 1463-1474. [CrossRef] [PubMed] 
24. Romero, G.Q.; Gonçalves-Souza, T.; Vieira, C.; Koricheva, J. Ecosystem engineering effects on species diversity across ecosystems: A meta-analysis. Biol. Rev. 2014, 90, 877-890. [CrossRef] [PubMed]

25. Passarelli, C.; Olivier, F.; Paterson, D.M.; Meziane, T.; Hubas, C. Organisms as cooperative ecosystem engineers in intertidal flats. J. Sea Res. 2014, 92, 92-101. [CrossRef]

26. Miller, R.J.; Page, H.M.; Reed, D.C. Trophic versus structural effects of a marine foundation species, giant kelp (Macrocystis pyrifera). Oecologia 2015, 179, 1199-1209. [CrossRef] [PubMed]

27. Schiel, D.; Foster, M. The Biology and Ecology of Giant Kelp Forest, 2nd ed.; University of California Press: Berkeley, CA, USA, 2015.

28. Ríos, C.; Arntz, W.E.; Gerdes, D.; Mutschke, E.; Montiel, A. Spatial and temporal variability of the benthic assemblages associated to the holdfasts of the kelp Macrocystis pyrifera in the Straits of Magellan, Chile. Polar Biol. 2007, 31, 89-100. [CrossRef]

29. Miller, R.J.; Lafferty, K.D.; Lamy, T.; Kui, L.; Rassweiler, A.; Reed, D.C. Giant kelp, Macrocystis pyrifera, increases faunal diversity through physical engineering. Proc. R. Soc. B 2018, 285, 20172571. [CrossRef] [PubMed]

30. Mayer-Pinto, M.; Ledet, J.; Crowe, T.P.; Johnston, E.L. Sublethal effects of contaminants on marine habitat-forming species: A review and meta-analysis. Biol. Rev. 2020, 95, 1554-1573. [CrossRef]

31. Evan, L.K.; Edwards, M.S. Bioaccumulation of copper and zinc by the giant kelp Macrocystis pyrifera. Algae 2011, 26, 265-275. [CrossRef]

32. Fink, L.A.; Manley, S.L. The use of kelp sieve tube sap metal composition to characterize urban runoff in southern California coastal waters. Mar. Pollut. Bull. 2011, 62, 2619-2632. [CrossRef] [PubMed]

33. Westermeier, R.; Murúa, P.; Patiño, D.J.; Muñoz, L.; Müller, D.G. Holdfast fragmentation of Macrocystis pyrifera (integrifolia morph) and Lessonia berteroana in Atacama (Chile): A novel approach for kelp bed restoration. J. Appl. Phycol. 2016, 28, 2969-2977. [CrossRef]

34. Contreras, L.; Bulboa, C.; Galbán, C.; Remonsellez, J.; Mella, D. Cultivo del alga parda Macrocystis pyrifera en la zona de Quintero y Puchuncaví: Evaluación de la productividad y potencial uso para biorremediación de metales pesados y compuestos orgánicos. 2017; N 30397482-0.

35. Pielou, E.C. Species-diversity and pattern-diversity in the study of ecological succession. J. Theor. Biol. 1966, 10, 370-383. [CrossRef]

36. Hubálek, Z. Measures of species diversity in ecology: An evaluation. Folia Zool. 2000, 49, 241-260.

37. Contreras-Porcia, L.; Meynard, A.; Lopez-Cristoffanini, C.; Latorre, N.; Kumar, M. Marine Metal Pollution and Effects on Seaweed Species. Chapter 3. In Systems Biology of Marine Ecosystems, 1st ed.; Kumar, M., Ralph, P., Eds.; Springer International Publishing AG: Berlin/Heidelberg, Germany, 2017; pp. 35-48.

38. Kumar, M.; Kumari, P.; Gupta, V.; Anisha, P.A.; Reddy, C.R.K.; Jha, B. Differential responses to cadmium induced oxidative stress in marine macroalga Ulva lactuca (Ulvales, Chlorophyta). Biometals 2010, 23, 315-325. [CrossRef]

39. Malea, P.; Rijstenbil, J.W.; Haritonidis, S. Effects of cadmium, zinc and nitrogen status on non-protein thiols in the macroalgae Enteromorpha spp. from the Scheldt Estuary (SW Netherlands, Belgium) and Thermaikos Gulf (N Aegean Sea, Greece). Mar. Environ. Res. 2006, 62, 45-60. [CrossRef] [PubMed]

40. Franklin, N.M.; Stauber, J.L.; Lim, R.P.; Petocz, P. Toxicity of metal mixtures to a tropical freshwater alga (Chlorella sp.): The effect of interactions between copper, cadmium, and zinc on metal cell binding and uptake. Environ. Toxicol. Chem. 2002, 21, $2412-2422$. [CrossRef]

41. Andrade, S.; Medina, M.H.; Moffett, J.W.; Correa, J.A. Cadmium-copper antagonism in seaweeds inhabiting coastal areas affected by copper mine waste disposals. Environ. Sci. Technol. 2006, 40, 4382-4387. [CrossRef]

42. Lewis, M.; Pryor, R. Toxicities of oils, dispersants and dispersed oils to algae and aquatic plants: Review and database value to resource sustainability. Environ. Pollut. 2013, 180, 345-367. [CrossRef]

43. Aksmann, A.; Tukaj, Z. The effect of anthracene and phenanthrene on the growth, photosynthesis, and SOD activity of the green alga Scenedesmus armatus depends on the PAR irradiance and $\mathrm{CO}_{2}$ level. Arch. Environ. Contam. Toxicol. 2004, 47, 177-184. [CrossRef]

44. Gauthier, P.; Norwood, P.; Prepas, E.; Pyle, G. Metal-PAH mixtures in the aquatic environment: A review of co-toxic mechanisms leading to more-than-additive outcomes. Aquat. Toxicol. 2014, 154, 253-269. [CrossRef]

45. Castilla, J.C. Food Webs and Functional Aspects of the Kelp, Macrocystis pyrifera, Community in the Beagle Channel, Chile; Siegfried, W.R., Condy, P.R., Laws, R.M., Eds.; Antarctic nutrient cycles and food webs; Springer: Berlin, Germany, 1985 ; pp. 407-414.

46. Adami, M.L.; Gordillo, S. Structure and dynamics of the biota associated with Macrocystis pyrifera (Phaeophyta) from the Beagle Channel, Tierra del Fuego. Sci. Mar. 1999, 63, 183-191. [CrossRef]

47. Graiff, A.; Pantoja, J.F.; Tala, F.; Thiel, M. Epibiont load causes sinking of viable kelp rafts: Seasonal variation in floating persistence of giant kelp Macrocystis pyrifera. Mar. Biol. 2016, 163, 1-14. [CrossRef]

48. Saunders, M.; Metaxas, A. Temperature explains settlement patterns of the introduced bryozoan Membranipora membranacea in Nova Scotia, Canada. Mar. Ecol. Prog. Ser. 2007, 344, 95-106. [CrossRef]

49. Fauchald, K.; Jumars, P.A. The diet of worms: A study of polychaete feeding guilds. Oceanogr. Mar. Biol. Annu. Rev. 1979, 17, 193-284.

50. Almanza, V.; Buschmann, A.H.; Hernández-González, M.C.; Henríquez, L.A. Can giant kelp (Macrocystis pyrifera) forests enhance invertebrate recruitment in southern Chile? Mar. Biol. Res. 2012, 8, 855-864. [CrossRef] 
51. Madariaga, D.J.; Ortiz, M.; Thiel, M. Demography and feeding behavior of the kelp crab Taliepus marginatus in subdital habitats dominated by the kelps Macrocystis pyrifera and Lessonia trabeculata. Invertebr. Biol. 2013, 132, 133-144. [CrossRef]

52. Contreras, L.; Medina, M.H.; Andrade, S.; Oppliger, V.; Correa, J.A. Effects of copper on early developmental stages of Lessonia nigrescens Bory (Phaeophyceae). Environ. Pollut. 2007, 145, 75-83. [CrossRef]

53. Roberts, D.A.; Poore, A.G.; Johnston, E.L. Ecological consequences of copper contamination in macroalgae: Effects on epifauna and associated herbivores. Environ. Toxicol. Chem. 2006, 25, 2470-2479. [CrossRef] 